\title{
Physiological response of different ground nut genotypes under semi-arid condition of Quetta Balochistan, Pakistan
}

\author{
Jahangir Ahmed ${ }^{1}$, Saadullah Khan Leghari ${ }^{2 *}$, Muhammed Asghar ${ }^{1}$, \\ Abdullah Baloch ${ }^{3}$, Muhammed Zeeshan Danish ${ }^{4}$, Abdul Razaq ${ }^{1}$, \\ Muhammed Youns ${ }^{5}$ and Rahim Shah ${ }^{1}$ \\ 1. Agriculture Research Institute Sariab Quetta, Pakistan \\ 2. Department of Botany University of Balochistan, Quetta, Pakistan \\ 3. Balochistan Agriculture Research \& Development Center Brewery Road, Quetta, Pakistan \\ 4. University College of Pharmacy, University of the Punjab, Lahore, Pakistan \\ 5. Department of Pharmacy University of Balochistan, Quetta, Pakistan \\ *Corresponding author's email: saadbotany@yahoo.com \\ Citation
}

Jahangir Ahmed, Saadullah Khan Leghari, Muhammed Asghar, Abdullah Baloch, Muhammed Zeeshan Danish, Abdul Razaq, Muhammed Youns and Rahim Shah. Physiological Response of different ground nut genotypes under semi-arid condition of Quetta Balochistan, Pakistan. Pure and Applied Biology. Vol. 5, Issue 2, 2016, pp332338. http://dx.doi.org/10.19045/bspab.2016.50043

Received: 28/10/2015 Revised: 26/03/2016

Accepted: 05/04/2016

Online First: 18/04/2016

\section{Abstract}

The groundnut genotypes including; BARI- 2011, BARD- 479, PG- 1102, PG- 492, PG- 1104 and Golden were assessed for agronomic stricture and yield stability at Quetta climatic condition during 2014. These genotypes were trialed in randomized complete block design with four replications. All the physiological parameters investigated among the groundnut genotypes showed significant variation. The genotype BARI- 2011 showed maximum yield potential $\left(1653.3 \mathrm{~kg} \mathrm{ha}^{-1}\right)$ fallowed by BARD- $479\left(1415.0 \mathrm{~kg} \mathrm{ha}^{-1}\right)$. Genotypes BARI- 2011 also demonstrated the high-quality consequence in the form of number of pod plant ${ }^{-1}$ (91.33), length of 20 pods $(75.00 \mathrm{~cm})$, and 100 kernels weight $(145.0 \mathrm{~g})$ whereas the genotypes PG-1104 indicated smallest amount of dry pod yield $\left(880.0 \mathrm{~kg} \mathrm{ha}^{-1}\right)$. The numbers of pod plant-1 (55.0) were showed lowest by PG- 492 whereas the length of 20 pods $(65.33 \mathrm{~cm})$ and weight of 100 kernels $(86.67 \mathrm{~g}$ ) was noted lowest in genotypes PG-1104. So based on yield potential, number of pod plant ${ }^{-1}$, length of 20 pods and weight of 100 kernels, the genotype BARI-2011 is suggested for wide-ranging farming in the semi-arid climatic condition of Quetta region and can be used for further breeding of groundnut.

Key words: Groundnut; Genotypes physiological response; Climatic condition; Balochistan

\section{Introduction}

Groundnut is the most important summer season cash crop in the world. It is grown-up in healthy drained sandy loam soils of Pakistan [1]. It is considered as a significant oil seed crop as well as foodstuff and feed crop. Its seed is full of both oil (43-55\%) and protein (25 - 28\%) [2]. In Pakistan its utilization is as roasted nuts, salting and in confectionery and its haulm is essential byproduct used for livestock feed. Groundnut is potential oil seed crop for the arid region 
and during 2008-2009, in Pakistan it was grown on an area of 980 hundreds hectare with a production of 85,500 tones and yield of $921 \mathrm{Kg} / \mathrm{ha}$ [3]. Rain fed area of about $58 \%$ of Balochistan remains fallow during summer season, due to which, there is the low annual income from the rain fed lands and an increased soil erosion problem during monsoon rains. The groundnut which is considered a drought tolerant high-income product and atmospheric gracious crop can be an alternate crop for the areas. In Pakistan the low yield of groundnut crop has been attributed due to the diverse climatic conditions and use of low yielding varieties [4].

Many investigators investigated the creative potential of groundnut genotype in diverse agro-ecological regions. The 12 groundnut genotypes were assessed at three locations in Malakand division and accounted important disparity for its attributes and yield [5]. Six groundnut genotypes were also investigated at Lasbella, Balochistan, Pakistan and reported major dissimilarity for the yield over the years and within the year [6]. On average, the maximum yield of $1341 \mathrm{~kg} \mathrm{ha}^{-1}$ given by the variety ICGS (E)-46 within consistent maturity and pod yield $1225 \mathrm{~kg} \mathrm{ha}$ ${ }^{1}$ as a minimum was recorded for the variety ICGS (E)-95. The groundnut variety R-8808 was examined at five locations (Dhawad, Lelgaum, Raichur, Bellary and Bijapur) at Karanatka, India and produced 30\% (1300 $\mathrm{kg} \mathrm{ha}^{-1}$ ) extra yield than the verified variety JL-24 (1000 kg ha-1) [7]. At Mumbai, India the groundnut variety TAG-24 was investigated and found to significantly maximum pod yield of $2665 \mathrm{~kg} \mathrm{ha}^{-1}$ besides the local verified variety with $2032 \mathrm{~kg} \mathrm{ha}^{-1}$ out of 11 varieties trial [8]. It was also reported by the researcher that the cross JL$24 \times$ Co-2 gave normal pod yield of 1790 and $2060 \mathrm{~kg} \mathrm{ha}^{-1}$ in rain fed and irrigated circumstances, respectively at Uther Pradesh, India [9]. For the maturation the crop needs 100-105 days. A trial carried out on 11 groundnut genotype reported that the genotypes K- 134, ICGS- 65 and ICGS - 44 were probably to be more flexible in rainfed situation of Northern Coastal zone of Andhra Pradesh, India [10]. The 13 genotypes of groundnut were investigated for two years at ARS, Swat, Pakistan and it was found that the genotypes SP-96 (4078 $\mathrm{kg} \mathrm{ha}^{-1}$ ), ICGS $99 \mathrm{~kg} \mathrm{ha}^{-1}$, ICGS 18 (4042 kg $\mathrm{ha}^{-1}$ ) and BARD-699 (4016 $\mathrm{Kg} \mathrm{ha}^{-1}$ ) gave considerably the maximum pod yield [11]. A large seeded groundnut variety for Brazil (BRS-151 Amendoim L 7) produced standard pod yield $1850 \mathrm{~kg} \mathrm{ha}^{-1}$ in rain fed and $4500 \mathrm{~kg} \mathrm{ha}^{-1}$ under irrigated circumstances [12]. An early groundnut, the Nonghua-22 was tested at four sites in China and accounted pod yield of 4021 and 4116 $\mathrm{kg} \mathrm{ha}^{-1}$ [13]. Other 20 genotypes groundnut variety were investigated at Swat, Pakistan and it was found that the genotypes, ICGS 7326 (3611 kg ha-1), ICGV $86028(3798 \mathrm{~kg}$ $\left.\mathrm{ha}^{-1}\right)$, BARD 479 (3889 $\left.\mathrm{kg} \mathrm{ha}^{-1}\right)$, PG 542 (3889 $\left.\mathrm{kg} \mathrm{ha}^{-1}\right)$, ICGS $50\left(3889 \mathrm{~kg} \mathrm{ha}^{-1}\right)$ and Cina (4528 kg ha-1), gave appreciably the highest pod yield besides the Swat Phalli-96 (check) with $2409 \mathrm{~kg} \mathrm{ha}^{-1}$ [14].

The present study was carried out to assess the six high yielding groundnut genotypes under the Quetta climatic condition for commercial cultivation.

\section{Materials and methods Cultivation}

For the cultivation the seeds of six genotypes groundnut including Golden, BARI- 2011, BARD- 479, PG- 1102, PG492, PG- 1104 and Golden were received from NARC, Islamabad and BARI, Chakwal. The experiment was done at Agriculture Research Institute Sariab Quetta (ARISQ) in 2014. Seeds were sown with the help of single row cotton drill in first week of April. The application of Randomized Completed Block design with four replications was made and plot size was kept 
at $4 \mathrm{~m} \times 1.8 \mathrm{~m}$. The space between the rows was kept $45 \mathrm{~cm}$. Before sowing the fertilizers such as Urea, Nitrophos and SOP were practiced at the rate of $60-60-25$ NPK kg ha-1. At flowering stage Gypsum was used by at $500 \mathrm{~kg} \mathrm{ha}^{-1}$. For proper irrigation the water was given for 6 times till maturity. Insecticides were applied on proper time as requirement. During the course of trial such parameters as Days to maturity, Pods plant ${ }^{-1}, 20$-pods length $(\mathrm{cm})$, 100-kernels weight (g) and Pod yield ( $\mathrm{kg} \mathrm{ha}$ $\left.{ }^{1}\right)$ were recorded and twenty plants were selected randomly from each plot and labeled and at maturity the digging of pods were started.

\section{Data collection and analysis \\ Days to maturity}

For counting days to maturity the method described by Khan et al. [15] was used. At the end of flowering stage in each subplot, 10 plants were uprooted. The numbers of mature pods were considered when they showed dark brownish and yellow veins on the inner side of shell with brownish yellow kernel testa. When the plants showed more than $60 \%$ growth the mature pods were counted from the total. It was considered best time for recording maturity data as noted by Khan et al. [4].

\section{Number of pods plant ${ }^{-1}$}

For the pods plant ${ }^{-1}$ data, randomly 20 plants were chosen from each plot and on average basis the numbers of pods plant ${ }^{-1}$ were recorded and counted.

\section{Weight of 100-kernels}

The weight of 100 kernels was measured as a seed size. It was the weight of 100 seeds from each plot in grams.

\section{Length of 20-pods}

For recording data about the length of pods 20 plants were selected arbitrarily from each plot. The measuring scale was used for the measurement of pods length. The pods of selected plants were positioned in vertical beside the measuring scale. The measurement was done in centimeter.

Yield of pod ( $\left.\mathrm{kg} \mathrm{ha}^{-1}\right)$

For recording the data about pod yield $(\mathrm{kg}$ $\mathrm{ha}^{-1}$ ), methods described by Khan et al. [15] was used. The plants were harvested from each plot then pods were dehydrated in sun and weighed for pod yield per subplot. The yield was changed into $\mathrm{kg} \mathrm{ha}^{-1}$ by means of following formula given by Khan et al. [15]. Pod yield $\left(\mathrm{kg} \mathrm{ha}^{-1}\right)=\left[\left(\right.\right.$ Pod yield plot $^{-1}(\mathrm{~kg}) /$ Plot size $\left.\left(\mathrm{m}^{2}\right)\right] \times 10,000 \mathrm{~m}^{2}$

\section{Statistical Analysis}

For the statistically analysis of data the analysis of variance (ANOVA) was used [16]. The consequences of differences among the means were compared by using Least Significant Difference (LSD) Test [17].

\section{Results and discussion \\ Days to maturity}

The result illustrated in Table 1 indicated that all the investigated genotypes groundnut were significant concerning to their number of days taken for maturity. In the present study the groundnut such as BARI- 2011 was matured former (132.33days) than others and the greatest days (161.0 days) were taken for maturity by the genotype PG1104. However Zamurrad et al. [18] reported that, genotypes PG-1102 and PG-1092 were matured earlier as compared to others genotypes when they were investigating the performance based evaluation of groundnut genotypes under medium rainfall conditions of chakwal. Ahmed and Rahim [19] also noted non-significant variations among groundnut genotypes for maturity but a significant difference existed for plant height. Nath and Alam [20] resulted low genotypic co-efficient of variation for the maturity days. The finding of other researchers [6, 21-22] supported these results as they reported significant variation in maturity time among different groundnut genotypes. 


\section{Number of pods plant ${ }^{-1}$}

The data regarding number of pods plant ${ }^{-1}$ revealed significant differences in number of pods plant ${ }^{-1}$ as shown in Table 1. Similar results were also reported by other workers $[18,19]$ as they pointed out significant differences for pod yield, 100 kernel weight and pods plant ${ }^{-1}$. In present investigation the minimum number of pods plant ${ }^{-1}$ (55.0) were recorded from the genotypes groundnut PG- 492 and Maximum were (91.33) in BARI- 2011, followed by genotypes groundnut PG- 1102 (70.33). These results were supported by other researchers [18] as they indicated the maximum number of pods (45) for BARI2011, followed by PG-1102 (42.3) while PG-1104 had minimum No. of pods plant ${ }^{-1}$ (21). Current findings are also recognized by other workers [18, 19]; they noticed significant differences for pod yield, 100 kernel weight and pods Plant ${ }^{-1}$. Karkannavar et al. [23] indicated that seed trailed was heritable as the variation regarding pods per plant and pod yield among different varieties could be explained in the form of pods plant ${ }^{1}$. Shah et al. [24] reported as the yield is positively correlated with pods plant ${ }^{-1}$ and found BARI-2011and PG-1102 with higher number of pods plant ${ }^{-1}$ produced higher pod yield.

\section{Length of 20-pods}

Data presented in Table 1 for the 20 pods length indicated a significant variation between ranges of genotypes. The investigation of Zamurrad et al. [18] also showed significant variation for twenty pods length. The genotypes groundnut diversity BARI- 2011 showed greatest 20-pods length $(75.0 \mathrm{~cm})$ which fallowed by BARD- 479 $(72.0 \mathrm{~cm})$ and the genotypes variety of PG1104 had lowest $(65.33 \mathrm{~cm}) 20$-pods length. However Zamurrad et al. [18] during investigation for the performance based evaluation of groundnut genotypes under medium rainfall conditions of Chakwal, reported the maximum 20-pods length (72 $\mathrm{cm})$ for the varieties PG-1092 and BARI2011, while check variety Golden had minimum $(57 \mathrm{~cm})$ 20-pods length. The variation in pod height/length may be attributed to specific genetic characteristics of these varieties. The finding of other investigators Khan et al. [15] matched with the present results as they reported important differences in twenty pods length among groundnut genotypes. Genetic properties of each types played important role for pod length. While this could also be brought to change in the soil structure, texture and soil fertility [19].

\section{Weight of 100-kernels}

Data about the weight of 100-Kernels demonstrated important diversity. The lowest 100-kernels weight $(86.67 \mathrm{~g})$ was documented for the genotypes PG-1104, while highest 100-kernels weight was recorded for the genotypes BARI- 2011 $(145.0 \mathrm{~g})$ followed by BARD- $479(107.3 \mathrm{~g})$. While, Zamurrad et al. [18] during their investigations also found significant differences in 100- kernels weight of different genotypes groundnut. They reported maximum 100-kernels weight for PG-1104 (63.3g) followed by BARI-2011 (60.7g) while minimum 100 kernels weight of $47.3 \mathrm{~g}$ was recorded for check variety Golden. Present results were also confirmed by the findings of other researchers $[18,22]$. They reported significant variations in 100 kernels weight among different genotypes groundnut. Further the findings of Khote et al. \& John et al. $[25,26]$ for kernel yield per plant showed high phenotypic coefficient of variation (PCV) their results were in accordance to the present investigation.

\section{Pod yield $\mathrm{kg} \mathrm{ha}^{-1}$}

There was a significant variation in the yield $\mathrm{kg} \mathrm{ha}^{-1}$ of pods among different groundnut genotypes as stated in Table 1. The genotypes BARI- 2011 showed maximum pod yield $\left(1653.3 \mathrm{~kg} \mathrm{ha}^{-1}\right)$ and genotypes 
PG- 492 indicated minimum pod yield $\left(880.0 \mathrm{~kg} \mathrm{ha}^{-1}\right)$. Similar results were also noted by Zamurrad et al. [18] as they found that the Varity BARI-2011 maximum pod yield $\left(3648 \mathrm{~kg} \mathrm{ha}^{-1}\right.$ ) while minimum pod yield $\left(2825 \mathrm{~kg} \mathrm{ha}^{-1}\right)$ was recorded for PG1104. These types of differences in the Pod yield of different genotypes were also noticed by other investigators $[6,15,18,22$, 27]. Karkannavar et al. [23] revealed that variation regarding pods per plant and pod yield between different varieties could be explained in terms of pods plant ${ }^{-1}$. Celal [28] also indicated the positive relationship for seed yield with pods plant $^{-1}$ and 1000 seed weight and pods plant ${ }^{-1}$.

Table 1. . Physiological Response of different groundnut genotypes under climatic semiarid condition of Quetta Balochistan, Pakistan

\begin{tabular}{l|lllcl}
\hline Varieties Name & $\begin{array}{l}\text { Days to } \\
\text { Maturity }\end{array}$ & $\begin{array}{l}\text { No. of pods } \\
\text { plant }^{-1}\end{array}$ & $\begin{array}{l}\text { 20 pods } \\
\text { length } \\
\text { (cm) }\end{array}$ & $\begin{array}{l}\text { 100kernels } \\
\text { weight } \\
(\mathbf{g})\end{array}$ & $\begin{array}{l}\text { Pod } \\
\text { yield } \\
\text { (kgha }^{-1} \text { ) }\end{array}$ \\
\hline BARI- 2011 & $132.33 \mathrm{D}$ & $91.33 \mathrm{~A}$ & $75.00 \mathrm{~A}$ & $145.00 \mathrm{~A}$ & $1653.3 \mathrm{~A}$ \\
BARD- 479 & $152.00 \mathrm{C}$ & $69.33 \mathrm{BC}$ & $72.00 \mathrm{~B}$ & $107.33 \mathrm{~B}$ & $1415.0 \mathrm{~B}$ \\
PG- 1102 & $152.67 \mathrm{BC}$ & $70.333 \mathrm{~B}$ & $68.00 \mathrm{C}$ & $96.67 \mathrm{BC}$ & $1103.0 \mathrm{C}$ \\
Golden & $153.00 \mathrm{BC}$ & $64.33 \mathrm{BC}$ & $67.66 \mathrm{CD}$ & $95.00 \mathrm{BC}$ & $1000.7 \mathrm{D}$ \\
PG- 492 & $156.00 \mathrm{~B}$ & $55.00 \mathrm{D}$ & $67.00 \mathrm{CD}$ & $95.00 \mathrm{BC}$ & $880.0 \mathrm{~F}$ \\
PG-1104 & $161.00 \mathrm{~A}$ & $61.00 \mathrm{CD}$ & $65.33 \mathrm{D}$ & $86.67 \mathrm{C}$ & $926.7 \mathrm{E}$ \\
Grand Mean & 151.17 & 68.556 & 69.167 & 104.28 & 1163.1 \\
C.V & 1.40 & 6.71 & 1.94 & 8.99 & 2.14 \\
\hline LSD5\% & 1.7321 & 3.7584 & 1.0954 & 7.6546 & 20.370 \\
\hline
\end{tabular}

\section{Conclusion}

Keeping in view the above mentioned investigation it was concluded that all the parameters among the genotypes showed important disparity under semi-arid climatic condition. Among all the examined varieties the genotype BARI- 2011 was out standing in yield potential followed by BARD- 479 . For yield contributing characters like number of pod plant $^{-1}, 20$ pods length, and 100 kernels weight genotypes BARI- 2011 once more demonstrated high-quality consequence. Therefore the genotype BARI2011 is suggested for wide-ranging farming in the semi-arid climatic condition and further use in breeding programs for groundnut. The genotypes PG- 492 showed nominal amount of dry pod yield that is why it should be avoided for the farming in semiarid condition of Quetta.

\section{Authors' contributions}

Conceived and designed the experiments: J Ahmed \& SK Leghari, Performed the experiments: R Shah \& A Baloch, Analyzed the data: J Ahmed \& SK Leghari, Contributed reagents/ materials/ analysis tools: A Razaq, M Yousaf \& M. Asghar, Wrote the paper: SK Leghari \& MZ Danish.

\section{References}

1. Mensah JK \& Obadoni B (2007). Effects of sodium azide on yield parameters of groundnut (Arachis hypogaea L.). African Journal of Biotechnology 6(6): 668-671.

2. Din N, Mahmood A, Khattak GSS, Saeed I \&. Hassan MF (2009). High yielding groundnut (Arachis hypogea L.) Variety "Golden". Pak J Bot 41(5): 2217-2222.

3. Agricultural Statistics of Pakistan (2008-2009). Govt. of Pakistan (www.pakistan.gov.pk) 
4. Khan N, Ullah F \& Imtiaz Uddin M (2009). Agronomic Characters of Groundnut Arachis Hypogaea Genotypes as affected by nitrogen and Phosphorus fertilization under rainfed condition. Electronic J Environ Agri \& Food Chem 8(1): 61-68.

5. Khan A, Rahim M, Khan A \& Khan MI (2001a). Yield response of groundnut genotypes under the sub-mountainous conditions of Malakand Division (NWFP), Pakistan. Pak J Biol Sci 4 (4):404-406.

6. Taran SA, Haq MI, Baguti RA \& Taran $\mathrm{N}$ (1998). Evaluation of groundnut varieties under irrigated condition in coastal area of Uthal, Baluchistan. Sarhad J Agric 14: 225-228.

7. Prakash BG, Sajjanar GM \& Naykar NY (1998). A promising groundnut variety, R8808, suitable for the northern dry zone of Karnataka. Int'l Arachis Newsletter 18: 8.

8. Kale DM, Badigannavar AM \& Murty GS (1999). Groundnut variety TAG-24 with potential for wider adoptability. Int'l Arachis Newsletter 19: 12-13.

9. Manoharan V, Ramalinggam RS, Vindhyavarman P \& Kalaimani S (1989). VRI-2: A new Spanish groundnut variety with drought resistance. Groundnut News 1: 3- 4.

10. Rajeshwari (1998). Evaluation of groundnut genotype for rainfed conditions in the northern coastal zone of Andhra Pradesh, India. Int'l Arachis Newsletter 19:13-15.

11. Khan A \& Rahim M (1998). High yielding groundnut genotypes for the North West Frontier Province, Pakistan. Int'l Arachis Newsletter 18: 18-19.

12. Santos RC (1998). EMBRAPA release BSR 151 Amendoim L 7, a large seeded groundnut cultivar for the northern region in Brazil. Int'l Arachis Newsletter 18: 1112.
13. Gao L, Jiang Z, Long B, Feng F \& Deng F (1996). Breeding an early and high yielding groundnut variety Nonghua -22 in China. Int'l. Arachis Newsletter 16: 89.

14. Khan A, Malik NJ, Rahim M \& Khan A (1998). Evaluation of groundnut genotype for harvest index. Sarhad $J$ Agric 14: 437 - 440.

15. Khan A, Bano A, Bakht J, Khan SA, Malik NJ \& Naz I (2009). Response of exotic Ground nut Genotypes to environmental diversities at higher altitude of Northern Pakistan. Sarhad J Agric 25(4): 545-550.

16. Gomez KA \& Gomez AA (1984). Statistical procedures for Agricultural research. Wiley New York, 680 pp.

17. Steel RGD \& Torrie JH (1984). Principles and Procedures of Statistics. 2nd Ed. McGraw Hill Book Company, Singapore pp: 173-7.

18. Zamurrad M, Tariq M, Shah FH, Subhani A, Ijaz M, Iqbal MS \& Koukab M (2013). Performance Based Evaluation of Ground nut Genotypes under Medium Rainfall conditions of Chakwal J AgriFood and Applied Sciences 1(1): 9- 12.

19. Ahmed N \& Rahim M (2007). Evaluation of promising ground nut (Arachis hypogees L.) varieties for yield and other characters $J$ Agric Res 45(3): $185-189$.

20. Nath UK \& Alam MS (2002). Genetic variability, heritability and genetic advance of yield and related traits of groundnut (Arachis hypogaea L.). J Bio Sci 2: 762-764.

21. Khan A, Rahim M, Khan MI \& Tahir M (2001b). Genetic variability and criterion for the selection of peanut genotypes. Pak J Agric Res 16(1): 9-12.

22. Shukla AK \& Rai PK (2014). Evaluation of ground nut genotypes for yield and quality traits. Annals of Plant and Soil Research 16(1): 41 - 44. 
23. Karkannavar JC, Venugopal R \& Goud JV (1991). Inheritance and linkages studies in cowpea (Vigna unguiculata). Indian J Gene 51: 203-207.

24. Shah MA, Rahim J, Hassan S, Rashid A \& Jan H (1993). Screening of mung bean genotypes for genetic parameters and protein content. Sarhad J Agri 9: 317-321.

25. Khote AC, Bendle VW, Bhave SG \& Patil PP (2009). Genetic variability, heritability and genetic advance in some exotic genotype of groundnut (Arachis hypogaea L.). Crop Research 37: 186-191.

26. John K, Vasanthi RP \& Venkateswarlu O (2007). Variability and correlation studies for pod yield and its attributes in $\mathrm{F} 2$ generation of six Virginia $\mathrm{x}$ Spanish crosses of groundnut (Arachis hypogaea L.). Legume Research 30: 292-296.

27. Khan A (2005). Physiological response of groundnut to growth regulators under drought stress. Ph. D Dissert. Deptt. Of Biology. Sci. Quaid-e-Azam Univ. Islamabad, Pakistan.

28. Celal Y (2004). Correlation and path coefficient analysis of seed yield components in the Narbon bean (Vicia narbonensis L.). Turk J Agric 28: 3716. 